\title{
Recasting trust and distrust in the boardroom
}

\section{Morris Mthombeni and Amon Chizema}

\author{
Morris Mthombeni is based \\ at Gordon Institute of \\ Business Science, \\ University of Pretoria, Illovo, \\ South Africa. \\ Amon Chizema is based at \\ School of Business and \\ Economics, Loughborough \\ University, Loughborough, \\ UK, and Gordon Institute of \\ Business Science, \\ University of Pretoria, \\ Johannesburg, South \\ Africa.
}

\begin{abstract}
Purpose - This study aims to analyse trust and distrust as specific board processes between the board chair and chief executive officer (CEO) aimed at reducing corporate governance (CG) risk partially mitigated by regnant CG mechanisms. This study incorporates the nascent literature that posits trust and distrust as two separate constructs that co-exist simultaneously to recasts them in the CG domain.

Design/methodology/approach - This paper analysed data from 20 in-depth interviews conducted with board representatives at four financial services firms in The Netherlands, South Africa and Zimbabwe.

Findings - This paper found that the foundational bases of the chair-CEO relationship determine how trust and distrust are apportioned between them, which impacts board dynamics. This paper also confirmed that the constructs of trust and distrust are separate thus do not sit at opposite ends of a single continuum. Finally, this paper found that high levels of task-based distrust (as opposed to mistrust) are necessary during periods of organisational distress and more effective if there are also high levels of relational trust between the parties.

Originality/value - This paper empirically examines the relationship between trust and distrust in CEO-chair dyadic relationships in multiple companies across multiple countries. This paper also introduces the concept of tempered trust, which is defined as interpersonal trust tempered by task-based distrust, recasting the traditional characterisation of trust and distrust in the CG domain, thereby making a useful contribution to the literature on board dynamics.
\end{abstract}

Keywords Board dynamics, Chairperson, Chief executive, Trust, Distrust

Paper type Research paper

\section{Introduction}

An underlying assumption in agency theory is that distrust, rather than trust, plays a dominant role in the regulation of governance actions and behaviours (Eisenhardt, 1989a; Roberts, 2001). This view places trust and distrust at the centre of the discourse on corporate governance (CG) relationships (Nicholson et al., 2017), constructs that are often considered to be the polar opposites of each other (Schoorman et al., 2007) and have been characteristic effects of accountability (Roberts, 2001). This study joins scholars that focus on directly revealing the mechanisms of trust in CG (Huse and Zattoni, 2008; Migliore and Horton DeClouette, 2011), in so doing deviates from the work of scholars that consider trust indirectly and alongside accountability (Roberts, 2001) or equate distrust with mistrust (Kostis and Näsholm, 2020) an effort to motivate for rigid control mechanisms (Roberts et al., 2005). Trust and distrust have been evaluated simultaneously by scholars from different and unconnected fields like coopetion (Raza-Ullah and Kostis, 2020) and sports leadership (O’Boyle et al., 2020), but this study is one of few CG studies to do so.

While governance mechanisms are implemented to counter the risks and uncertainties (Elkelish, 2018) that give rise to distrust and mistrust (which is distinct from distrust) (Kostis and Näsholm, 2020), some researchers have shown that their increased use paradoxically leads to even higher levels of distrust (Goranova et al., 2017). Such scholars, who suggest 
that relying on agency theory solutions amplifies the negative effects of distrust (CuevasRodríguez et al., 2012; Goranova et al., 2017), may find solace in stewardship theory which suggests that managers are not motivated by individual goals but are instead stewards whose motives are aligned with the objectives of principals in an organisation (Löhde et al., 2021).

In this paper, we challenge and aim to recast the current boardroom logic that is informed by traditional theoretical depictions of trust and distrust as polar opposites in CG literature (Roberts, 2001) and tease out the more nuanced internal relationships of the board of directors that drive the effectiveness of boards (Sur, 2014). We build on the extant literature on trust between CG actors ((Huse and Zattoni, 2008; Price et al., 2018) and add to recent scholarship that acknowledges the co-existence of trust and distrust (Kostis and Näsholm, 2020; Schillemans and Bjurstrøm, 2020) in the boardroom (Nicholson et al., 2017).

Relying on a multi-disciplinary, multi-theoretic and multi-country approach (Mnif and Borgi, 2020), our intention is to illustrate contribute to the re-conceptualisation of trust and distrust as essential and complementary constructs between board chairs and chief executive officers (CEOs) in a manner that could reveal additional and more effective CG mechanisms (Garg and Eisenhardt, 2017; Koskinen and Lämsä, 2017; Krause, 2017; Mostovicz et al., 2011; Schillemans and Bjurstrøm, 2020; Sur, 2014; Watson et al., 2021). To this end, our research question is:

$R Q 1$. How does trust and distrust influence effective board dynamics, focussing specifically on the role of the board chair and CEO?

Our study aims to contribute to the literature of $C G$ and to practice. First, the study seeks to contribute to the growing body of literature that is calling for better understanding of CG processes (Nicholson et al., 2017), going beyond the characterisation of governance through structure. Second, our study seeks to improve our understanding of the concepts of trust and distrust in $C G$ and demonstrate the conditions under which distrust is considered useful.

\section{Literature review}

\section{Trust and distrust - bipolar or separate constructs in corporate governance}

Trust refers to a person's belief that another party to a transaction or relationship will make sincere efforts to uphold commitments and not take advantage of them, given the opportunity (Rousseau et al., 1998). Yet there is a risk that the other party may not behave predictably and will instead use guile to act in their own self-interest. Therefore and in general, trust is depicted as occurring under conditions of risk and as a mechanism for reducing uncertainty (Skinner and Spira, 2003). This requires the trusting party (the "trustor") to develop sufficiently favourable expectations of the intentions and behaviour of the other party (the "trustee") to prompt a willingness to become vulnerable to the trustee's future conduct (Grobler and Hotlzhausen, 2018; Mayer et al., 1995; Rousseau et al., 1998).

Definitions of distrust typically use trust as the reference point. Consider the distrust defined as "confident negative expectations regarding another's conduct" (Lewicki et al., 1998, p. 439). As such, most researchers conceptualise trust and distrust as "antithetical" (Bigley and Pearce, 1998, p. 407), at mutually exclusive ends of a single, continuous construct (Migliore and Horton DeClouette, 2011). According to this traditional view, a "complete lack of trust and distrust are the same thing" (Schoorman et al., 2007, p. 350). This view is consistent with earlier conceptualisations of distrust as an "absence of faith in other people" (Ross et al., 2001, p. 569). Here, the general positivity bias in the trust literature, which rarely engages with the negative consequences of trust like unethical behaviour (Chen and Eweje, 2020), supports this positioning of distrust (Gargiulo and Ertug, 2006; Yenkey, 2018) and 
the theoretical tendency to treat unknown entities with suspicion (Dimoka, 2010; Granovetter, 1985).

Crucially, these depictions of trust and distrust are unrealistic and contribute to simplistic characterisations of organisational risk within the CG domain (Cuevas-Rodríguez et al., 2012; De Maere et al., 2014). For instance, some scholars have noted that relying on agency theory amplifies the effects of organisational risk within CG (Beccerra and Gupta, 1999; Cuevas-Rodríguez et al., 2012; De Maere et al., 2014). Others have stated that relying on stewardship theory, which overemphasises the role of trust, elides the negative consequences of trust (Skinner et al., 2013). Yet other scholars have found that underemphasising distrust minimises the expected effects of organisational risk (Mayer et al., 1995) and results in negative consequences for organisations.

The question of whether trust and distrust can co-exist has also been probed from different perspectives including game theory (Gezelius, 2007; Chattoe-Brown, 2011), sociology (Edwards et al., 2006) and psychology (Robinson and Rousseau, 1994). Dimoka (2010) studied trust and distrust within the field of neuroscience. Using functional neuroimaging (fMRI) tools, she asserted that "observing the location, timing and level of brain activity that underlies trust and distrust and their underlying dimensions [...] trust and distrust activate different brain areas and have different effects" (Dimoka, 2010, p. 373). While this view is gaining traction in other areas (Casado-Aranda et al., 2019; Kostis and Näsholm, 2020; Lumineau, 2017; Nicholson et al., 2017), it is still a gap to be investigated in the CG domain.

Investigating this gap is made all the more pressing given the mischaracterisation of the approach by Lewicki et al. (1998). Scholars like Migliore and Horton DeClouette (2011) position Lewicki's et al.'s (1998) definition of distrust as part of a continuum from trust as the positive and distrust as the negative, when in fact, Lewicki et al. (1998) were among the first to argue that trust and distrust can be considered as separate constructs as opposed to a continuum on opposite ends of each other.

Notably, current CG thinking and practices favour the employment of structural mechanisms to mitigate agency problems that influence organisational performance (Boivie et al., 2016; de Barros et al., 2021; Goodman et al., 2021; Muchemwa et al., 2016; Tshipa et al., 2018). Indeed, one of the consequences of agency theory-based uncertainty between principals and agents is goal conflict. Agency theory has reduced the relationship between principals and agents to an atomistic, goal-conflicted one (Aguilera and Jackson, 2003; Clacher et al., 2010; Davis, 1991), which amplifies mistrust (Kostis and Näsholm, 2020) and leaves little room for trust. However, stewardship theory is an alternative to agency theory, creating the possibility of more trust in the stewardship role of agents (Wright et al., 2001). Stewardship theory characterises managers positively, viewing them as intrinsically motivated people whose self-image is linked to the success of the organisation and not their own personal success (Löhde et al., 2020; Hernandez, 2012; Tshipa et al., 2018). Neither theory helps us to understand how helps scholars to understand how directors process information to make effective decisions.

\section{Board information process}

Fulmer and Gelfand (2012) proposed the concept of need for certainty, grounded in the theory of need for closure (NFC), to help understand dispositions to trust in organisational context. Scholars interested in trust have investigated NFC as a motivating factor and have argued that it influences information searching and processing by exchange parties (AcarBurkay et al., 2014). NFC has been defined as a need for firm answers when confronted with an uncertain situation (Acar-Burkay et al., 2014). In a discussion about NFC, AcarBurkay et al. (2014) referred to two epistemic processes: seizing (quick judgements or impressions) and freezing (rigidity or flexibility of thought). In addition, they distinguished between uncertainty-oriented individuals and certainty-oriented ones and stated that an

PAGE 1006 | CORPORATE GOVERNANCE $\mid$ VOL. 22 NO. 52022 
individual's attitude towards certainty is influenced by NFC (Acar-Burkay et al., 2014). HighNFC individuals seek stability by urgently settling on judgements (seizing and freezing), while low-NFC individuals are more open to new sources of information and tend to suspend judgement (Acar-Burkay et al., 2014). High-NFC individuals are quick to trust (or distrust), which is proxy for swift trust - an unsustainable form of trust (Dietz and Den Hartog, 2006). Low-NFC individuals are slow to trust in others, but this does not hinder their ability to collaborate during early phases of trust development (Dietz and Den Hartog, 2006). This suggests that low-NFC individuals are more likely to approach trust and distrust as separate mechanisms and may be better at building sustained trust with unknown others.

According to Acar-Burkay et al. (2014), certainty-oriented individuals tend to have either high or low trust in others. High-NFC individuals show more trust for close others and less trust for distant others, but low-NFC individuals show equal regard for close and distant others because they resolve uncertainty through an evidence-based, sense-making approach espoused by Rousseau (2006). Therefore, we suggest that NFC moderates exchanges that rely on interpersonal closeness. Also, Acar-Burkay et al. (2014) indicated that NFC is a property of individuals. Therefore, the concept of NFC may contribute to illuminating dispositions to trust between individuals in power positions like the chair and CEO, naturally where such roles have been separated.

\section{The board chair and chief executive officer relationship}

With reference to the literature acknowledging the separation of the roles of CEO and chair, which is consistent with the resource dependency theory (Garg and Eisenhardt, 2017; Withers and Fitza, 2017), the CEO leads the business while the board chair leads the board in a manner that is dichotomously portrayed in agency theory (Morais et al., 2020). Consistent with the view that trust and distrust are separate constructs (Casado-Aranda et al., 2019; Kostis and Näsholm, 2020) when the board chair simultaneously operationalises the positive dimensions of trust and distrust in the CEO, the board benefits from having leaders whose primary focus is practising good governance, maintaining ethical standards and building the board into an effective leadership team (Chen and Eweje, 2020; Sur, 2014; Withers and Fitza, 2017).

From the description of the chair's and CEO's respective roles, especially where decisionmaking is concerned, the two individuals have to engage constantly (Garg and Eisenhardt, 2017). This suggests that some sort of interpersonal relationship exists between them, based either on trust or distrust. Yet we know very little about the chair-CEO relationship, at least empirically (Morais et al., 2020). For example, without specifically referring to the chair and CEO, Westphal (1999, p. 9) developed a "collaborative board model" that concluded that board effectiveness may be improved by close, trusting CEO-board relationships, combined with moderate to high levels of CEO incentive alignment. Therefore, it is fair to conclude that board chairs that simultaneously operationalise trust and distrust in the CEO may contribute to board effective board dynamics, an area of CG that has long been called for investigation (Kakabadse et al., 2001). This view is consonant with balancing reliance on agency and stewardship theories (Nicholson et al., 2017; Schillemans and Bjurstrøm, 2020). This view is consonant with balancing reliance on agency and stewardship theories (Nicholson et al., 2017; Schillemans and Bjurstrøm, 2020).

\section{Research questions}

Taking the agency and stewardship perspectives together as reviewed in this study and applying trust and distrust to the under researched interpersonal relationship between the CEO and board chair, this study offers the following propositions: 
P1. Boards with a high distrust in the CEO have high levels of CEO monitoring. Conversely, boards with a high level of trust in the CEO have low levels of CEOmonitoring.

$P 2$. Board chairs that simultaneously operationalise trust and distrust in the CEO contribute to healthy board dynamics.

These two propositions are explored using the following three research questions, which combine trust and distrust literature with compositional and behavioural studies of CG:

$R Q 2$. What can we learn from corporate governance relational practices to establish whether trust and distrust are useful operationalised as a single continuum (i.e. antithetical) or as separate constructs?

$R Q 3$. Consistent with conduct and behaviour scholars in corporate governance, how do trust and distrust mechanisms influence informal corporate governance mechanisms?

RQ4. Consistent with scholarship concerned with structure and composition in corporate governance, how do trust and distrust mechanisms influence formal corporate governance mechanisms?

\section{Method}

While we know much about board governance and performance (Muchemwa et al., 2016; Taljaard et al., 2015; Tshipa et al., 2018), we know even less about board governance and effectiveness in emerging markets (Sur, 2014; Tsamenyi et al., 2007), especially in Africa, a region that is persistently under-researched (Mnif and Borgi, 2020). To address this gap in our understanding, unlike much of the CG literature that focusses shareholder or stakeholder interests based on quantitative data that is easy to access (Gabrielsson and Huse, 2004) and invariable treating the board itself as a black box, the analytical focus of this study is aimed at hard to access qualitative data of the board itself (Leblanc and Schwartz, 2007; Roberts, 2011) leading to better understanding of how boards actually work. Consequently, we can shift from knowing very little about the relationships between key actors on the board and how these impact board effectiveness (Garg and Eisenhardt, 2017).

At the suggestion of Ketokivi and Choi (2014) and using case studies, we adopted an exploratory approach to theory development. The case study method enabled us different methods of collecting data to gain a deeper understanding of context specific phenomena (Silvestri and Veltri, 2017). According to Yin (2009), the case study is the preferred method when conducting exploratory research. Therefore, we opted for a multi-country and multiple case study research design. The multiple case study approach is better suited to developing a rich, reliable, analytically and limitedly generalisable theoretical framework (Ellram, 1996; Gehman et al., 2018), which improves external validity (Eisenhardt, 1989b; Yin, 2009). The units of analysis in our study were the chair-CEO dyads and their key followers, especially chief financial officers (CFOs), of financial service companies (banks and insurance companies). In particular, the financial services context is salient because agency theory has been shown to be ineffective in efforts to mitigate risk and uncertainty in this regulated sector (Elkelish, 2018).

\section{Research setting}

To understand board effectiveness in distressed organisations (Shipley and Kovacs, 2008; Sur, 2014) and informed by the relationship between the board chair and the CEO (Morais et al., 2018), we considered four cases of financial service companies in distress: two companies from South Africa, one from The Netherlands and one from Zimbabwe. Our focus on companies in South Africa and Zimbabwe alongside The Netherlands was in 
response to calls for board governance studies to focus on different emerging market contexts (Tsamenyi et al., 2007), especially in Africa (Mnif and Borgi, 2020) and seek comparison with established markets.

Given the qualitative nature of the study, where most studies typically have small sample sizes (Chen and Eweje, 2020), this study borrowed from post-positivist traditions in qualitative studies that have a slightly larger and more diverse sample size (Cucari, 2019).

The current study was a critical realism, which builds on the tenets of post-positivism (Danermark et al., 2002; Easton, 2010). Given that this study relies on primary as opposed to proxy data, it is worth noting that the sample size of this study is one of its distinguishing features especially given how board governance actors are perennially hard to access (Leblanc and Schwartz, 2007; Nicholson et al., 2017). Whereas prior studies in difficult-toaccess subjects like boards have suggested a focus on gatekeepers (Reeves, 2010), this study relied on multiple tactics including the use of social networks and social capital (Fulmer and Gelfand, 2012), credibility building informed by signal theory where interviews took comfort in knowing that one of the authors was an experienced director of companies (Bijlsma-Frankema and Costa, 2005). Accordingly, gaining access to the directors of companies in the selected companies and across multiple countries demonstrated that with appropriate credibility building strategies, it is possible to gain access where many board governance scholars fail.

Organisational distress triggers change management situations that are often regarded as ideal settings for researching potentially contrasting cognitions and emotions (Piderit, 2000). In some studies, such situations have been used to provide the context for understanding trust (Sørensen et al., 2011), but less frequently, trust and distrust (Saunders and Thornhill, 2004). In such situations, well-managed change has tended to be associated with employee trust, whereas badly managed change has tended to be associated with employee mistrust (which is the absence of trust and is different from distrust) (Kostis and Näsholm, 2020; Sørensen et al., 2011). We, therefore, examined the dynamics of trust and distrust (but not mistrust) between the board chair and the CEO in our chosen contexts.

The two South African companies were Protea and Fynbos. Protea was a listed insurance company experiencing endogenously caused financial distress. It had been in existence for over 50 years. Our access to Protea was limited to a few interviewees. Fynbos was an unlisted, regulated public insurance company experiencing exogenously caused financial distress. It had also been in existence for over 50 years. We had full access to the Fynbos board and management. The third company, Hibiscus, was a Zimbabwean bank experiencing endogenously caused financial distress. Hibiscus had been in existence for more than 50 years. The fourth company was Tulip, the Netherlands-based bank experiencing endogenously caused financial distress. Tulip was more than 150 years old. We had limited formal access to both banks outside of South Africa.

\section{Theoretical sampling}

We used a threefold theoretical approach when selecting cases for the study (Eisenhardt, 1989b). First, we selected cases that highlighted trust and distrust from a multi-theory perspective - cases that exemplified agency theory and stewardship theory conditions. Second, we selected cases (drawn from the developed North and the underdeveloped South) with strong national ties, which enabled us to interrogate whether national institutional context (and not culture) was a factor in CG processes. Third, we selected cases where firms were in a distressed rather than in a healthy state. Given that we were pursuing theoretical sampling, we were not motivated by a need to be representative as would be expected when pursuing statistical sampling in explanatory studies. 


\section{Data collection and analysis}

Consistent with other CG scholars, qualitative data used in this case study method was collected using semi-structured interview question (Grant and McGhee, 2017). We collected data by conducting 20 in-depth, semi-structured interviews with board chairs, CEOs, CFOs and other non-executive board members (in some of the cases). Because it is usually very difficult to gain access to directors (Leblanc and Schwartz, 2007), we mainly (but not exclusively) focussed on the board chair, CEOs and CFOs, with each interview lasting between 60 and $120 \mathrm{~min}$. Participants were encouraged to speak freely, the questions having been designed to solicit their views on the levels of trust and of distrust between the board chair and CEO.

We performed rigorous and abductive thematic data analysis, informed by perspectives from the literature on CG and trust, respectively (Danermark et al., 2002; Easton, 2010; Eisenhardt, 1989b). This abductive thematic analysis is "located within the interpretivist paradigm [that] seeks to understand the social reality of governance work" (Grant and McGhee, 2017, p. 5). To this, we used the Atlas.ti system and followed a four-stage model:

1. preparing the data files;

2. sorting the data;

3. coding the data; and

4. "discovering patterns, processes, sequences, or typologies" (Friese, 2014, p. 15).

We used the data from the four exemplar cases because "the process of data collection and analysis was a continuous one that stopped only when this iterative process had reached saturation" (Burden and Roodt, 2007, p. 12). When saturation was reached (Vollstedt, 2015), we discontinued the data analysis. Although there is no "agreed method for establishing saturation" (Francis et al., 2010, p. 1229) in this study, theoretical saturation was reached after 20 interviews had been analysed.

\section{Findings}

\section{RQ1: Trust and distrust: as a single continuous or separate constructs}

From the interviews conducted across the four case studies, we found that the chair-CEO relationships varied in several ways - from values and professional and contractual issues to formal and informal governance mechanisms (Goodman et al., 2021). Three key findings emerged. First, we found that the foundational bases of the chair-CEO relationship determines the trust and distrust mix, which has implications for effective board dynamics.

Second, we found that the constructs of trust and distrust were separate in each of the four cases and not located at mutually exclusive ends of a single, continuous construct, as some previous studies have shown (Schoorman et al., 2007). This observation is consistent with nascent trust and distrust literature (Kostis and Näsholm, 2020; Lewicki et al., 1998; Nicholson et al., 2017). We added to previous work by establishing that trust and distrust are not only separate but are also divergent at the high end (high trust/high distrust) and convergent at their low points (low trust/low distrust) and that they are perpendicular to each other, as shown in Figure 1, which also shows the four firms in our study mapped on the axes that illustrate the trust and distrust dimensions.

Third, informed by the context of our study of distressed firms, we found evidence of a new combination of high levels of trust and distrust not previously specified in literature on trust or $C G$, that is, because it is necessary for the market to develop confidence in the board of distressed firms, such firms have to exercise high levels of task-based distrust. Yet high task-based distrust mechanisms are most effective in situations where high relational trust 


\section{Figure 1 Tempered-trust model}

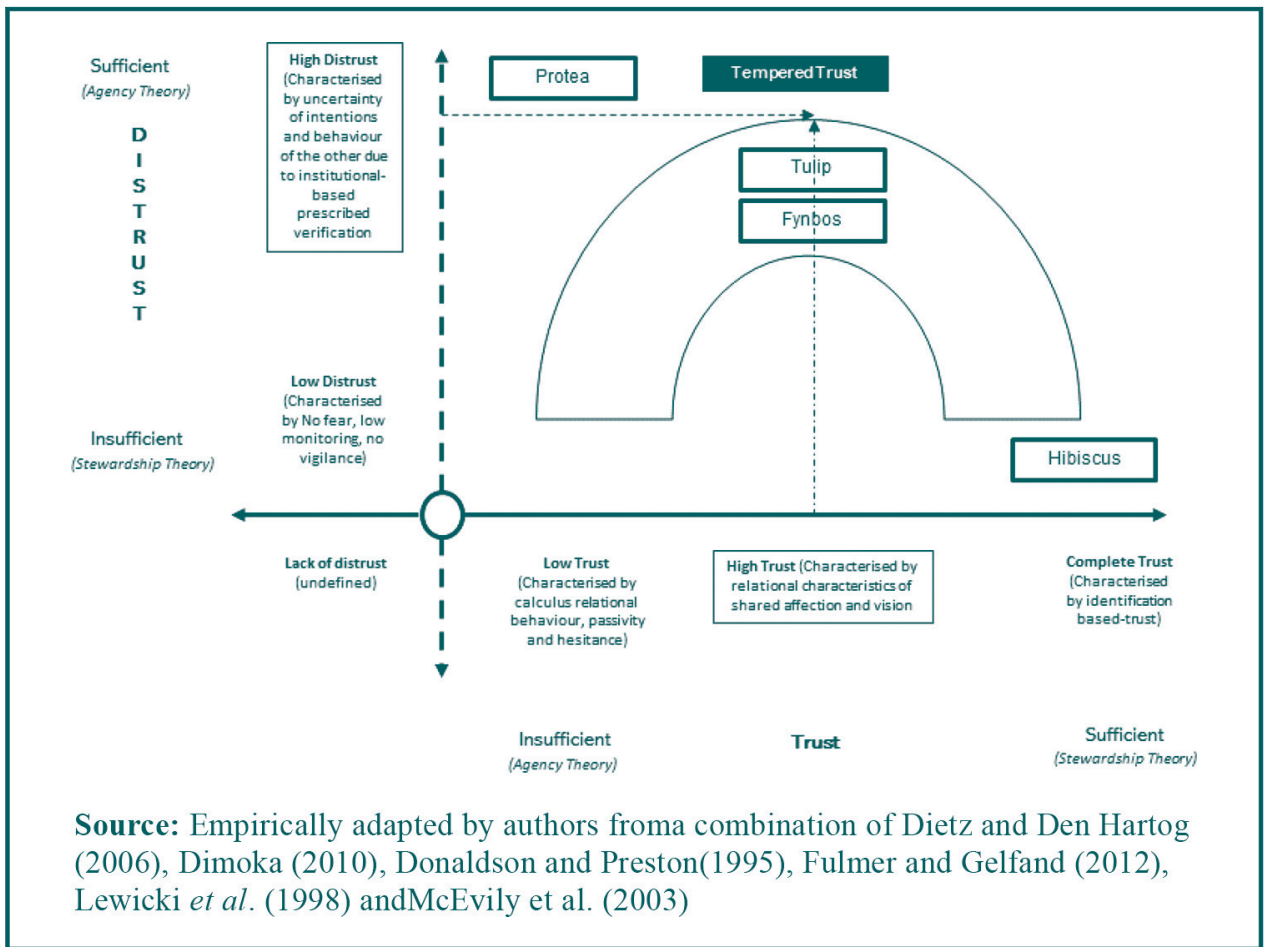

exists. This finding contradicts the view that high levels of general distrust potentially destroy trust.

As shown in Figure 1, the location of Protea on the distrust-trust axes suggests that the relationship between the chair and the CEO was characterised by low trust and high distrust. Their interpersonal relationship was weak and there was heavy reliance on distrust mechanisms, specifically task-based distrust, suggesting the use of formal CG mechanisms, especially the monitoring of tasks. The position of Fynbos suggests that the relationship between the chair and the CEO was characterised by high relational trust and high task-based distrust. Their interpersonal relationship was strong and the firm used robust, formal CG mechanisms, akin to task-based distrust, aimed at aligning the interests of management with those of shareholders.

The location of Tulip is similar to that of Fynbos, suggesting that the relationship between the chair and the CEO was characterised by high relational trust and high task-based distrust. Thus, Tulip used both distrust and trust CG mechanisms. We found that relational trust at Tulip was necessary for the task-based distrust mechanisms to operate effectively and furthermore that effective task-based distrust mechanisms strengthened the relational trust relationship. The location of Hibiscus suggests that the relationship between the chair and the CEO was characterised by high trust and low distrust. In the case of Hibiscus, there was a paradoxical finding in terms of which the interpersonal relationship between the chair and the CEO was neutral. So, while the firm relied less on formal CG mechanisms, it relied more on professional excellence as a proxy for trustworthiness. From the interviews, we found that this relationship dynamic between the chair and the CEO also existed between other members of the board and top management.

Importantly, Figure 1 illustrates a form of trust which we refer to as tempered trust and define as the intersection of relational-based trust and task-based distrust. Tempered trust is a form of trust that is consistent with the academic agreement about declines among social actors in trust (Crane, 2020; Kong et al., 2014) and increases in distrust 


\section{Table 1 Definitions of distrust}

\begin{tabular}{lll} 
Orientation & DEFINITIONS & AUTHOR(S) \\
\hline Certainty- oriented & $\begin{array}{l}\text { A complete lack of trust } \\
\text { Absence of faith in other people } \\
\text { A belief that a person's values or motives will } \\
\text { cause them to approach all situations in an } \\
\text { unacceptable way }\end{array}$ & $\begin{array}{l}\text { Schoorman et al. (2007) } \\
\text { Ross et al. (2001) } \\
\text { Sitkin and Roth (1993) }\end{array}$ \\
& $\begin{array}{l}\text { Confident negative expectations regarding } \\
\text { another's conduct; a fear of, a propensity to } \\
\text { attribute sinister intentions to, or a desire to } \\
\text { buffer oneself from the effects of another's } \\
\text { conduct } \\
\text { Negative expectations regarding another's } \\
\text { conduct } \\
\text { Expectations of injurious actions }\end{array}$ & Lumineau (2017) \\
& $\begin{array}{l}\text { Lewicki et al. (1998) } \\
\text { Source: Authors }\end{array}$ & Luhmann (1979) as \\
& cited in Kramer (1999)
\end{tabular}

(Kramer, 1999; Lewicki et al., 1998) in organisations and organisational actors like top management and the board. Tempered trust is a form of trust predicated on incorporating positive aspects of distrust into efforts to reconceptualise trust and distrust relevant in the CG domain consistent with what Lumineau (2017) describes as "bidimensional models of trust" (p. 1556).

\section{RQ2: Informal governance mechanisms}

In response to the second and third questions, the elements and interviewee representations of trust and distrust between the chair and CEO in the different case study firms are presented in Table 2 below. This foregrounds the interplay between informal and formal governance mechanisms, leading to a consideration of how such mechanisms respond to the research question and propositions of this study.

\section{Informal governance mechanisms}

Relationships and mutual alignment were found to activate informal governance mechanisms between the chair and the CEO. While a prior interpersonal relationship between the chair and the CEO can be an advantage in some instances, it can be a disadvantage in others. Professionally based relationships were found to sustain the relational alignment between the chair and the CEO. These findings were derived from four themes that underpin informal governance mechanisms (see Table 3).

Interpersonal relationships. We found that when a prior relationship existed between the board chair and CEO, any organisational distress tended to give rise to interpersonal or shared pain since both parties were jointly involved in dealing with the distress. This type of interpersonal pain was induced by the strain placed on their relationship. Consider the situation when the Tulip CEO looked to his chair during a shareholder dispute:

It was a very lonely period because the Chairman, in his role as supervisory board member and the controlling shareholder of Green Holdings, couldn't afford to say, "Guys, this is my fight," so he positioned it as a fight between Blue Bank and management, which it was [...] It was a very tough time, very stressful and that's when the loneliness comes in, because then you're out there on your own (Tulip, CEO).

From insights acquired when studying Fynbos and Protea, we concluded that an overreliance on personal relationships may heighten the risk of negative relational dynamics 


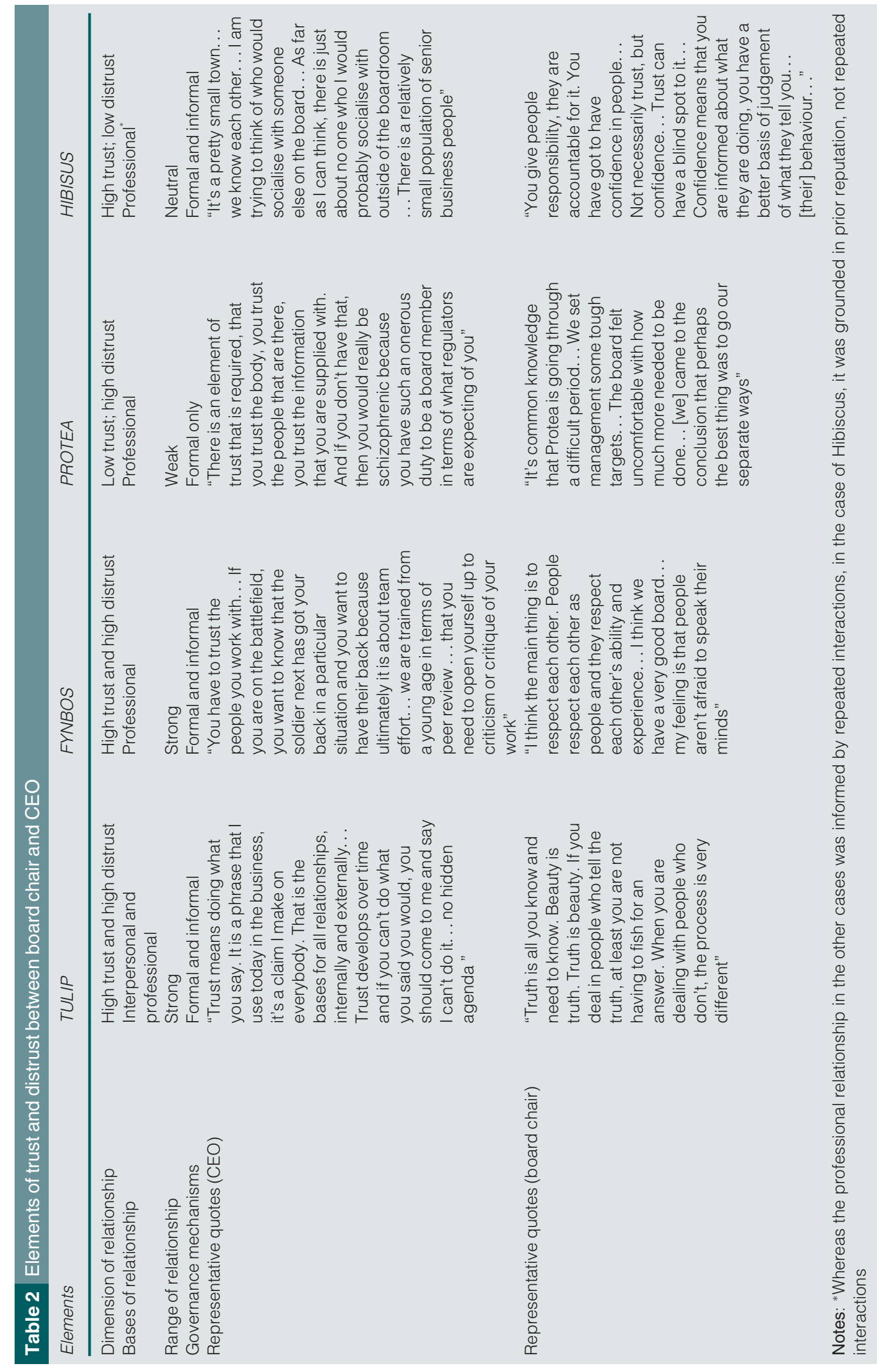


Table 3 Informal sense-making themes

B. Sense-making through professional relationships

C. Sense-making through transparency

A Sense-making through interpersonal relationships $\quad$ D. Sense-making relational alignment

Source: Authors

between the chair and CEO during periods of organisational distress. Such negative relational dynamics that are occasioned by a type of interpersonal trust could lead to antisocial behaviours and elevated agency risks. While past interpersonal interactions acted as a positive variable in the growth of the business since they had trust-building benefits, those interactions developed into an unproductive over-reliance on trust during times of distress. Therefore, the data from this theme suggests a tempered reliance on interpersonal relations consistent with $P 1$.

Professional relationships. We found that to have healthy board dynamics, it is crucial to establish a professional basis for interactions - even where prior personal relationships exist, as was the case with Tulip and Fynbos. We found that professional-based rather than personal or relationship-based are better able to address principal-agency problems because professional relationships are influenced by verified evidence. This contradicts the long-established practice of selecting CEOs and board chairs predominantly on the basis of interpersonal factors (Westphal and Zajac, 1995; Withers et al., 2012).

Our findings from the four case studies also revealed that evidence-based decision-making is a hallmark of professional relationships. Moreover, a professionally based relationship between the chair and the CEO could be influenced either by homogeneous or heterogeneous historical and professional factors. A review of the Hibiscus and Fynbos case studies led us to conclude that when a relationship is based on a homogeneous professional history, the chair and CEO are likely to rely on similar ideologies, concepts, frameworks and theories to process and interpret data - in other words, "sense-making" (Weick, 1993). Therefore, the chair-CEO dyadic pair at Hibiscus, Fynbos and Tulip benefited from shared beliefs (Chattopadhyay, 2003) and possibly also from shared characteristics (Fulmer and Gelfand, 2012), both of which positively affected board dynamics.

Conversely, data from the Protea interviews indicated that when a relationship is based on heterogeneous professional histories, the chair and CEO are likely to use different ideologies, concepts, frameworks and theories to process and interpret data. Although articulating their different approaches to sense-making during meetings is necessary to take the edge off their heterogeneous backgrounds, it is insufficient. The CEO and chair need to intentionally develop a shared approach to sense-making, which was not evident at Protea. Data relating to this theme partially illuminate elements of $P 2$.

Alignment through transparency. In the Protea case, we also found that while the chair and CEO revealed their sense-making differences to each other, their reasons for doing so were not aligned. This contributed to their failure to develop a shared approach and, in turn, constrained sense-making between them. Consider the Protea CEO's reflections on his relationship gap with the chair:

[...]when I reflect on it now, the person who was my Chairman versus the person that was there before, we did not have a forthright conversation (Protea, CEO).

In this regard, we found that the absence of shared beliefs and characteristics may heighten task-based distrust. Building on the Protea case, we assert that a heterogeneous professional relationship is characterised by the chair needing regular, verified information from the CEO. Consider the sentiment that "reflecting on it, I don't believe we had a 
respectful relationship" (Protea, CEO). This requirement is a sign of a distrust-based relationship between the chair and the CEO, as trust scholars have established that verification is an indicator of distrust (Tomlinson and Mayer, 2009; Audi et al., 2016). Consequently, the data from this theme is supportive of $P 1$.

Relational alignment processes. The analysis of Fynbos and Hibiscus suggests that the relational alignment between the chair and the CEO contributed to the creation of a functional board dynamic, where trust and distrust occurred in a complementary manner. Conversely, the misalignment between the chair and the CEO at Protea contributed to a dysfunctional board dynamic, where trust and distrust operated in an incompatible manner. The misalignment was also found in the breakdown of trust at Protea, which created an environment of high distrust and low trust between the chair and CEO (Kakabadse et al., 2006). To ensure that a board of directors operates optimally, we suggest that CEOs and chair should work towards both relational and professional alignment. The Hibiscus CEO spoke about this topic:

In a board context, I think one of the biggest challenges for non-executive directors is that you are reliant on the information that is presented to you [...] So, a good non-executive will always probe, ask questions, try and look for the information that is not necessarily presented, or the syntheses or views that are not necessarily put forward and try and extract [...] a more balanced view (Hibiscus, CEO).

Evidence from the four case studies suggests that the mechanisms to align a chair and a CEO are influenced by the context of their relationship and that the alignment process in a healthy business environment is different from that in a distressed business environment. In a healthy environment, such as at Hibiscus, the chair and members of the board are less critical of information provided by the CEO because they rely on evidence of the CEO's business success. We, therefore, believe that trust mechanisms are more likely to be misused in healthy business environments, where they are least required. Therefore, this data partially illuminates $P$ 2.

\section{Formal governance mechanisms}

Where formal mechanisms are concerned, we focussed primarily on themes titled timely information requirements, verifiable information and consensus-based decision-making. These themes are reflected in Table 4 below and elaborated in this section.

Sense-making through timely information. We found in both the Tulip and Protea cases that the CEO provided regular, verified information to a distrust-oriented chair because this helped the chair gain confidence in what the CEO communicated. From the Protea case data, we found that the CEO's failure to understand the chair's information requirements resulted in their information-sharing sessions being detrimental to their attempts to trust each other

From the Tulip case data, we found that, due to the chair's and CEO's mutual respect for each other, their information exchanges helped build trust between them. The CEO influenced this process by presenting the type of information that the chair desired and expected. We, therefore, suggest that a better working relationship between a CEO and a distrust-oriented chair can be achieved if the former adopts a strategy of providing accurate

Table 4 Sense-making themes

B. Sense-making through verification

C. Sense-making through consensus

A Sense-making through timely information

Source: Authors

VOL. 22 NO. $52022 \mid$ CORPORATE GOVERNANCE $\mid$ PAGE 1015 
and timely information to the latter. As the Tulip CEO said, "we started these long processdriven sessions, because the Chairman is a very process-driven man" (Tulip, CEO).

A distrust-oriented CEO, who relies on the strength of facts despite the strength of personal relationships, is more likely to quickly understand the information requirements of a distrustoriented chair because of their similar sense-making orientations. In contrast, a trustoriented CEO who relies on the strength of personal relationships rather than the strength of facts is less likely to understand the information requirements of a distrust-oriented chair.

From the Protea and Tulip case studies, we found it possible to extrapolate that as long as there is respect between the parties, distrust-based relationships can lead to positive outcomes. The presence or absence of respect within a distrust-based relationship provides further support for a distinction to be made between distrust and lack of trust with a lack of trust being tempered by the presence or absence of respect. While respect was initially not a focal point in this study, scholars have noted that it is an antecedent to cooperation (San Martín-Rodríguez et al., 2005), which is a factor that reinforces trust: the more a person cooperates and demonstrates trustworthy intentions, actions and behaviours, the more that person builds his or her trustworthiness. The data in this theme is supportive of $P 2$.

Sense-making through verification. In all four cases, when business deteriorated or the firm became distressed, members of the board and the chair focussed less on performance outputs and more on activity inputs because declining performance elevates environmental uncertainty and task-based distrust. We found that elevated task-based distrust triggered different outcomes. In a relational context, where task-based distrust occurred with low interpersonal trust, the outcomes were negative, but where task-based distrust occurred with high interpersonal trust, the outcomes were positive.

The foregoing discussion suggests that task-based distrust is a potentially useful mechanism in trusting, mutually respectful relationships between governance actors because the individuals concerned are not threatened by increased scrutiny of their actions or tasks. For instance, the Fynbos chair stated, "So, in a good board, someone can take a stand on an issue and not destroy relationships" (Fynbos, Chair). The very act of submitting to increased scrutiny could be seen as a sign of the CEO's relational trust in the board. For example, increased scrutiny was intended to resolve the organisational distress caused by factors external to Fynbos, as shown in Table 2. The data underpinning this theme were supportive of $P 2$.

Sense-making through consensus. One of the key findings emerging from the case studies was that boards of directors whose relational dynamic was professionally based preferred consensus-based decision-making to voting-based decision-making. Generally, consensus-based decision-making is characterised by high trust in a person and high distrust in the claims made by the person until such claims are verified. Homogeneous, professional relationships are more likely to be aligned than heterogeneous ones. However, the latter type could achieve high relational effectiveness if both the chair and the CEO make their differences explicit and actively try to make things work. Participants from all four cases mentioned the importance of actively seeking consensus in the boardroom.

Consider comments by the Hibiscus CEO on this topic:

I think we try and build that consensus, it is very rare that we get to the point of taking a vote and having a split decision on which way we go. I am trying to think if it has ever happened, but it is extremely rare that we get to that position. So, no, I think generally we have got there by consensus (Hibiscus CEO).

We found that relationships mainly based on personal interactions were more likely to rely on trust and less on distrust. However, relationships based on professional interactions were more likely to use a combination of trust and distrust mechanisms. Findings from two 
of the four case studies indicated that institutional distrust mechanisms that focussed on tasks can be combined with respect-based generative processes to reinforce relational trust. In Protea, we found that excessive use of institutional distrust mechanisms in distressed organisations can cause the distress to deepen. Therefore, the empirical data suggested that respect-based generative processes, coupled with shared sense-making, may be related to cooperation, which is an antecedent to perceived trustworthiness. Once again, the data from this theme was supportive of $P 2$.

\section{Summary findings}

In summary, two of the four themes that emerged from the data in relation to the informal governance mechanism were supportive of $P 1$. There other two themes partially illuminated specific aspects of $P 2$, but not all. However, the findings of three themes that explain the formal governance mechanisms were supportive of $P 2$. Therefore, the empirical data indicates propositions derived from the multi-disciplinary literature facilitate the answering of the research question in the affirmative and in a nuanced manner that foregrounds the internal dynamics of board chairs and CEOs aimed at effective board dynamics.

\section{Discussion and conclusion}

The empirical data positively addresses the research question by supporting the propositions in two novel ways. First, the empirical data is supportive of the claim that trust and distrust are separate constructs, these two constructs are actually perpendicular, converging at their low points (that is, low trust/low distrust). Through informal governance mechanisms, this is firmly supportive of our first proposition, which points to different roles of trust and distrust on the monitoring function of the agentic and stewardship boards. Second, when firms are facing difficulties and are in need of market approval and legitimacy, the mechanisms of high trust and high distrust can be effectively combined. Therefore and through some informal and all formal governance mechanisms identified in this study, the data supports $P 2$ by illustrating that the point of intersection between high trust and high distrust represents a form of trust that we refer to as tempered trust, where the relationship between the board chair and the CEO can best be described as collaborative. Our study, therefore, also provides empirical evidence in support of Westphal's (1999) collaborative board model.

We also believe that our study has illuminated different manifestations of agency-based and stewardship-based behaviour in boardrooms at distressed firms (Schillemans and Bjurstrøm, 2020). For instance, our analysis of empirical data from the Protea case study revealed a relationship dynamic between the chair and the CEO that was misaligned $a b$ initio because of institutional distrust mechanisms that the chair used (consistent with agency theory), while the CEO naively clung to relational trust mechanisms to regulate their mutual relationship (consistent with stewardship theory) (Davis et al., 1997).

The Hibiscus case study (with high trust and low distrust) provided an opportunity to analyse a stewardship-oriented board (Davis et al., 1997; Hernandez, 2012; Muth and Donaldson, 1998) that had clear boundaries between its management team and the board, while the chair and CEO had complementary leadership roles and relations. The stewardship-oriented board was evidenced in data showing that the board was stable, committed and professional and that the relational engagement between board members and between the board and management was positive. Because of this professional and collegial approach to engaging, governance actors at Hibiscus cooperated well, even when dealing with difficult issues that could have exposed affected individuals and the firm to risk.

The Fynbos and Tulip case studies (exemplars of tempered trust) provided empirical data on a high trust and high distrust relationship between the chair and the CEO, a relationship scholars have described as sacred (Kakabadse et al., 2006), especially in distressed firms. 
This type of relationship in both firms contributed to healthy relationships between board members, between the board and management and between members of the management team. Our empirical findings of the simultaneous operation of trust and distrust, as revealed in the Fynbos and Tulip case studies, were in contrast to the theoretically derived opinion of some scholars that institutional distrust, based on agency theory's need for control and monitoring functions, discourages the development of relational trust between governance actors (Sundaramurthy and Lewis, 2003; Westphal and Gulati, 1999). Therefore, these case studies indicated that high trust and high distrust, when triggered simultaneously to invoke tempered trust, introduced in this study during a period of organisational distress, contribute to effective board dynamics.

The Fynbos and Tulip case studies showed the effects of a high task-based distrust and a high interpersonal trust-based relationship and - the perfect intersection between agency (Jensen and Meckling, 1976) and stewardship theories (Davis et al., 1997). Because of the high interpersonal trust relationship evident in both cases, governance actors were willing to embrace task-based distrust mechanisms of verification when the context demanded their deployment. This suggests that, instead of discounting trust, agency theory scholars should borrow from stewardship theory by accommodating relational trust in their CG debates (Beccerra and Gupta, 1999; Schillemans and Bjurstrøm, 2020). This study provides a new angle to scholarly efforts to integrate the trust and distrust in CG literatures (Blair and Stout, 2001) as reflected in the trust and distrust governance framework depicted on Figure 2 below. Firstly, the study considers the conditions under which formal and informal governance mechanisms invoke trust and distrust to improve the relationship between the board chair and the CEO. Secondly, the study focusses on institutional contexts of distress to highlight the role of context in the efficacy of CG mechanisms (Tihanyi et al., 2015), incorporating the tempered trust concept derived from this study and indicated in Figure 1 above.

\section{Implications of the study for theory}

Previous agency theory and stewardship theory studies have, respectively, argued that trust and distrust are mutually exclusive constructs. We differ with this framing on four accounts. First, we maintain that these constructs should be viewed both as separate and

\section{Figure 2 Trust and distrust governance framework}

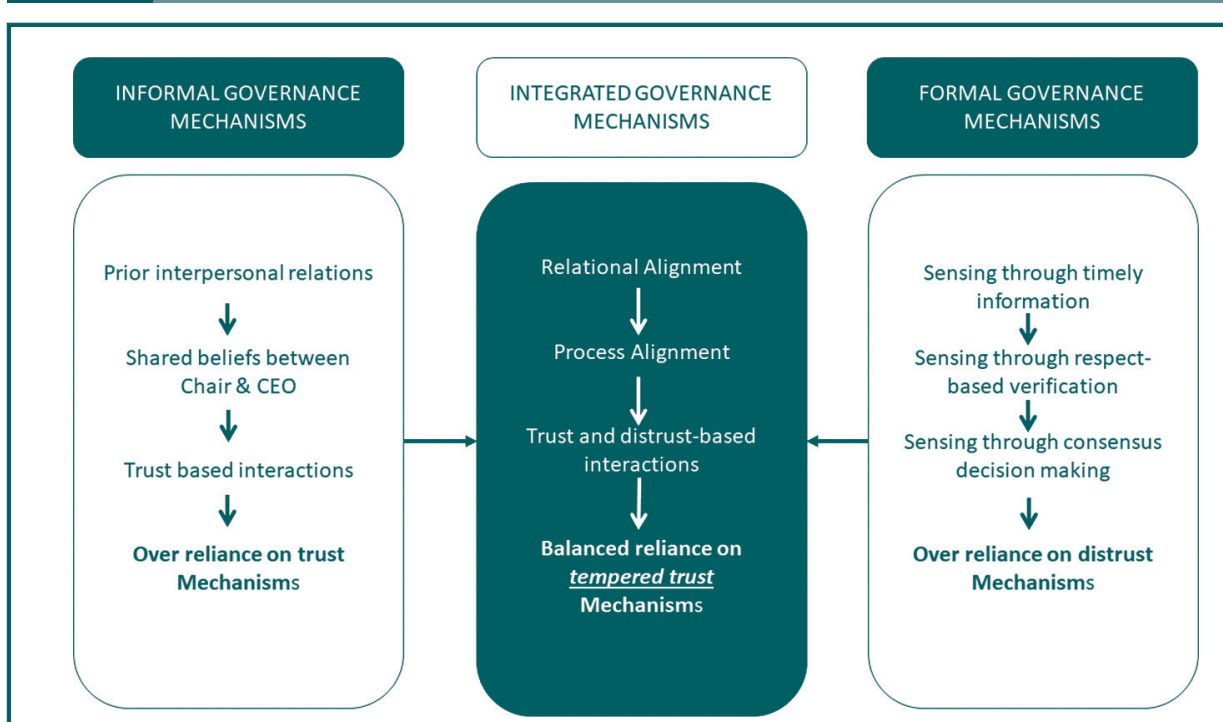

Source: Authors 
perpendicular to each other, converging at points of low trust and low distrust and diverging at points of high trust and high distrust. Second, our findings suggest that when firms are in distress, high levels of task-based distrust are necessary but are more effective when there are also high levels of relational trust as captured in the newly introduced concept of tempered trust - a meso and micro interplay. Third, we introduce the concept of tempered trust, recasting the traditional characterisation of trust and distrust in the CG domain. Fourth, we also introduce the trust and distrust framework incorporating the tempered trust concept as the integrating mechanism of trust and distrust in CG. In doing so, our fourfold contribution to literature contributes to illuminating effective board dynamics.

\section{Implications of the study for practice}

Our study provides a message to policymakers and governance practitioners, especially those located in the global South, that current CG specifications and processes may be under-emphasising how the effectiveness of boards may be enhanced by incorporating the nature of the relationships between key board actors as opposed to mimicking structural mechanisms that dominate CG literature and practices from the global North. Embracing relational aspects of CG may ameliorate the shortage of board skills and experience in emerging market contexts, a view advance by Mans-Kemp et al. (2020).

Specifically, by introducing the concept of tempered trust and re-specifying the trust and distrust mechanisms in the CG domain, we suggest that to achieve effective board effectiveness - alongside regnant institutional mechanisms (formal) that focus on activities and tasks - the chair and CEO should place equal importance on relational governance processes (informal) relative to formal CG mechanisms. Chairs and CEOs should work collaboratively, leveraging high levels of task-based distrust enabled by formal mechanisms while also ensuring high levels of relational trust operationalised through informal mechanisms.

\section{Limitations and suggested future research}

Despite the timeliness, relevance and insightfulness of this study, it had certain limitations. First, there are different types of CG system across the world, as noted by Aguilera and Jackson (2003), with some using one-tier or unitary boards and some using two-tier boards. In this study, the combined case studies featured three unitary boards and one two-tier board, but the differences in their generative mechanisms were not observed. Second, according to the CG literature, boards behave like teams (Tuggle et al., 2010). Our focus was on the relationship between the chair and the CEO only (Morais et al., 2018; Nicholson et al., 2017). Future studies could consider more cases reflecting the two-tier board system, with a stronger focus on their antecedents and, in addition, could compare the dynamics of boards in which the roles of chair and CEO are separated and combined, respectively. Future studies could also consider multiple relationships in the boardroom, thereby providing greater insight into board dynamics. Third, this study focussed on trust and distrust, as opposed to mistrust (Kostis and Näsholm, 2020). Future studies could simultaneously explore trust, distrust and mistrust in the boardroom. Finally, as novel as the findings of this study may be and consistent with findings from qualitative studies, they can only be generalised to a limited extent (Payne and Williams, 2005).

\section{References}

Acar-Burkay, S., Fennis, B.M. and Warlop, L. (2014), "Trusting others: the polarization effect of need for closure”, Journal of Personality and Social Psychology, Vol. 107 No. 4, pp. 719-734.

Aguilera, R.V. and Jackson, G. (2003), "The cross-national diversity of corporate governance: dimensions and determinants", Academy of Management Review, Vol. 28 No. 3, pp. 447-465. 
Audi, R., Loughran, T. and McDonald, B. (2016), "Trust, but verify: MD\&A language and the role of trust in corporate culture”, Journal of Business Ethics, Vol. 139 No. 3, pp. 551-561.

Barros, F.E.E.D., Santos, R.C.D., Orso, L.E. and Sousa, A.M.R. (2021), "The evolution of corporate governance and agency control: the effectiveness of mechanisms in creating value for companies with IPO on the Brazilian stock exchange", Corporate Governance: International Journal of Business in Society, Vol. 21 No. 5, pp. 775-814.

Beccerra, M. and Gupta, A. (1999), "Trust within the organization: integrating the trust literature with agency theory and transaction costs economics", Public Administration Quarterly, Vol. 23 No. 2, pp. 177-203.

Bigley, G.A. and Pearce, J.L. (1998), "Straining for shared meaning in organization science: problems of trust and distrust”, The Academy of Management Review, Vol. 23 No. 3, pp. 405-421.

Bijlsma-Frankema, K. and Costa, A.C. (2005), "Understanding the trust-control nexus", International Sociology, Vol. 20 No. 3, pp. 259-282.

Blair, M.M. and Stout, L.A. (2001), "Trust, trustworthiness and behavioural foundations of corporate law", University of Pennsylvania Law Review, Vol. 149 No. 6, pp. 1735-1810.

Boivie, S., Bednar, M.K., Aguilera, R.V. and Andrus, J.L. (2016), "Are boards designed to fail? The implausibility of effective board monitoring", Academy of Management Annals, Vol. 10 No. 1, pp. 319-407.

Burden, J. and Roodt, G. (2007), "Grounded theory and its application in a recent study on organisational redesign: some reflections and guidelines", SA Journal of Human Resource Management, Vol. 7 No. 1, pp. 11-18.

Casado-Aranda, L.A., Dimoka, A. and Sánchez-Fernández, J. (2019), "Consumer processing of online trust signals: a neuroimaging study", Journal of Interactive Marketing, Vol. 47, pp. 159-180.

Chattoe-Brown, E. (2011), "Combining ethnography and game theory using simulation: a critique and development of "can norms account for strategic action?", Sociology, Vol. 46 No. 2, pp. 339-353.

Chattopadhyay, P. (2003), "Can dissimilarity lead to positive outcomes? The influence of open versus closed minds", Journal of Organizational Behavior, Vol. 24 No. 3, pp. 295-312.

Chen, M.S. and Eweje, G. (2020), "Establishing ethical guanxi (interpersonal relationships) through Confucian virtues of xinyong (trust), lijie (empathy) and ren (humanity)", Corporate Governance: The International Journal of Business in Society, Vol. 20 No. 1, pp. 1-15.

Clacher, I., Hillier, D. and McColgan, P. (2010), “'Agency theory: incomplete contracting and ownership Structure'", in Baker, H.K. and Anderson, R. (Eds), Corporate Governance: A Synthesis of Theory, Research and Practice, John Wiley \& Sons, Hoboken, NJ, pp. 141-156.

Crane, B. (2019), "Qualitative comparative analysis in corporate governance research: a systematic literature review of applications", Corporate Governance: The International Journal of Business in Society, Vol. 19 No. 4, pp. 717-734.

Crane, B. (2020), "Revisiting who, when, and why stakeholders matter: trust and stakeholder connectedness", Business and Society, Vol. 59 No. 2, pp. 263-286.

Cucari, N. (2019), "Qualitative comparative analysis in corporate governance research: a systematic literature review of applications", Corporate Governance: The International Journal of Business in Society, Vol. 19 No. 4, pp. 717-734.

Cuevas-Rodríguez, G., Gomez-Mejia, L.R. and Wiseman, R.M. (2012), "Has agency theory run its course?: making the theory more flexible to inform the management of reward systems", Corporate Governance: An International Review, Vol. 20 No. 6, pp. 526-546.

Danermark, B., Ekstrom, M., Karlsom, J.C. and Bashkar, R. (2002), Explaining Society: An Introduction to Critical Realism in Social Sciences, Routledge, New York, NY.

Davis, G.F. (1991), "Agents without principles? The spread of the poison pill through the network inter corporate", Administrative Science Quarterly, Vol. 36 No. 4, pp. 583-613.

Davis, J.H., Schoorman, F.D. and Donaldson, L. (1997), "Toward a stewardship theory of management", Academy of Management Journal, Vol. 22 No. 1, pp. 20-47.

De Maere, J., Jorissen, A. and Uhlaner, L.M. (2014), "Board capital and the downward spiral: antecedents of bankruptcy in a sample of unlisted firms", Corporate Governance: An International Review, Vol. 22 No. 5, pp. 387-407. 
Dietz, G. and Den Hartog, D.N. (2006), "Measuring trust inside organisations", Personnel Review, Vol. 35 No. 5, pp. 557-588.

Dimoka, A. (2010), "What does the brain tell us about trust and distrust? Evidence from a functional neuroimaging study", MIS Quarterly, Vol. 34 No. 2, pp. 373-396.

Donaldson, T. and Preston, L.E. (1995), "The stakeholder theory of the corporation: concepts, evidence and implications", The Academy of Management Review, Vol. 20 No. 1, pp. 65-91.

Easton, G. (2010), "Critical realism in case study research", Industrial Marketing Management, Vol. 39 No. 1, pp. 118-128.

Edwards, P., Bélanger, J. and Wright, M. (2006), "The bases of compromise in the workplace: a theoretical framework", British Journal of Industrial Relations, Vol. 44 No. 1, pp. 125-145.

Eisenhardt, K.M. (1989a), "Agency theory: an assessment and review", The Academy of Management Review, Vol. 14 No. 1, pp. 57-74.

Eisenhardt, K.M. (1989b), "Building theories from case study research", The Academy of Management Review, Vol. 14 No. 4, pp. 532-550.

Elkelish, W.W. (2018), "Corporate governance risk and the agency problem", Corporate Governance: The International Journal of Business in Society, Vol. 18 No. 2, pp. 254-269.

Ellram, L.M. (1996), "The use of the case study method in logistics research", Journal of Business Logistics, Vol. 17, pp. 93-138.

Francis, J.J., Johnston, M., Robertson, C., Glidewell, L., Entwistle, V., Eccles, M.P. and Grimshaw, J.M. (2010), "What is an adequate sample size? Operationalising data saturation for theory-based interview studies", Psychology \& Health, Vol. 25 No. 10, pp. 1229-1245.

Friese, S. (2014), Qualitative Data Analysis with Atlast.ti, 2nd ed., Sage Publications, London.

Fulmer, C.A. and Gelfand, M.J. (2012), "At what level (and in whom) we trust: trust across multiple organizational levels", Journal of Management, Vol. 38 No. 4, pp. 1167-1230.

Gabrielsson, J. and Huse, M. (2004), "Context, behavior and evolution: challenges in research on boards and governance", International Studies of Management \& Organization, Vol. 34 No. 2, pp. 11-36.

Garg, S. and Eisenhardt, K.M. (2017), "Unpacking the CEO-board relationship: how strategy making happens in entrepreneurial firms", Academy of Management Journal, Vol. 60 No. 5, pp. 1828-1858.

Gargiulo, M. and Ertug, G. (2006), "'The dark side of trust”, ', in Bachmann, R. and Zaheer, A. (Eds), Handbook of Trust Research, Edward Elgar, Cheltenham, pp. 165-186.

Gehman, J., Glaser, V.L., Eisenhardt, K.M., Gioia, D., Langley, A. and Corley, K.G. (2018), "Finding theory-method fit: a comparison of three qualitative approaches to theory building", Journal of Management Inquiry, Vol. 27 No. 3, pp. 284-300.

Gezelius, S. (2007), "Can norms account for strategic action? Information management in fishing as a game of legitimate strategy", Sociology, Vol. 41 No. 2, pp. 201-218.

Goodman, J., Pearson, H. and Mthombeni, M. (2021), "Sources of accountability in the boardroom", European Business Review, Vol. 33 No. 4, pp. 667-691.

Goranova, M.L., Priem, R.L., Ndofor, H.A. and Trahms, C.A. (2017), "Is there a "dark side" to monitoring? Board and shareholder monitoring effects on M\&A performance extremeness", Strategic Management Journal, Vol. 38 No. 11, pp. 2285-2297.

Granovetter, M. (1985), "Economic action and social structure: the problem of embeddedness", American Journal of Sociology, Vol. 91 No. 3, pp. 481-510.

Grant, P. and McGhee, P. (2017), "Personal moral values of directors and corporate governance", Corporate Governance: The International Journal of Business in Society, Vol. 17 No. 1, pp. 1-12.

Grobler, A. and Holtzhausen, M.M. (2018), "Supervisory trust to be earned: the role of ethical leadership mediated by person-organisational fit", South African Journal of Economic and Management Sciences, Vol. 21 No. 1, pp. 1-11.

Hernandez, M. (2012), "Toward an understanding of the psychology of stewardship", Academy of Management Review, Vol. 37 No. 2, pp. 172-193. 
Huse, M. and Zattoni, A. (2008), "Trust, firm life cycle and actual board behavior: evidence from 'one of the lads' in the board of three small firms", International Studies of Management \& Organization, Vol. 38 No. 3, pp. 71-97.

Jensen, M.C. and Meckling, W.H. (1976), "Theory of the firm: managerial behavior, agency costs and ownership structure", Journal of Financial Economics, Vol. 3 No. 4, pp. 305-360.

Kakabadse, A., Ward, K., Korac-Kakabadse, N. and Bowman, C. (2001), "Role and contribution of nonexecutive directors", Corporate Governance: The International Journal of Business in Society, Vol. 1 No. 1, pp. 4-8.

Kakabadse, A.P., Kakabadse, N.K. and Barratt, R. (2006), "Chairman and chief executive officer (CEO): that sacred and secret relationship", Journal of Management Development, Vol. 25 No. 2, pp. 134-150.

Ketokivi, M. and Choi, T. (2014), "Renaissance of case research as a scientific method", Journal of Operations Management, Vol. 32 No. 5, pp. 232-240.

Kong, D.T., Dirks, K.T. and Ferrin, D.L. (2014), "Interpersonal trust within negotiations: Meta-analytic evidence, critical contingencies, and directions for future research", Academy of Management Journal, Vol. 57 No. 5, pp. 1235-1255.

Koskinen, S. and Lämsä, A.M. (2017), "Development of trust in the CEO-chair relationship", Baltic Journal of Management, Vol. 12 No. 3, pp. 274-291.

Kostis, A. and Näsholm, M.H. (2020), "Towards a research agenda on how, when and why trust and distrust matter to coopetition", Journal of Trust Research, Vol. 10 No. 1, pp. 66-90.

Kramer, R.M. (1999), "Trust and distrust in organizations: emerging perspectives, enduring questions", Annual Review of Psychology, Vol. 50, pp. 569-598.

Krause, R. (2017), "Being the CEO's boss: an examination of board chair orientations", Strategic Management Journal, Vol. 38 No. 3, pp. 697-713.

Leblanc, R. and Schwartz, M.S. (2007), "The black box of board process: gaining access to a difficult subject”, Corporate Governance: An International Review, Vol. 15 No. 5, pp. 843-851.

Lewicki, R.J., McAllister, D.J. and Bies, R.J. (1998), "Trust and distrust: new relationship and realities", The Academy of Management Review, Vol. 23 No. 3, pp. 438-458.

Löhde, A.S.K., Campopiano, G. and Calabrò, A. (2021), "Beyond agency and stewardship theory: shareholder-manager relationships and governance structures in family firms", Management Decision, Vol. 59 No. 2, pp. 390-405.

Luhmann, N. (1979), "Trust and power", Willey, Chichester.

Lumineau, F. (2017), "How contracts influence trust and distrust", Journal of Management, Vol. 43 No. 5 , pp. 1553-1577.

McEvily, B., Perrone, V. and Zaheer, A. (2003), "Trust as an organizing principle", Organization Science, Vol. 14 No. 1, pp. 91-103.

Mans-Kemp, N., Viviers, S. and Weir, J. (2020), "Investigating the extent and impact of director overboardedness using a comprehensive measure", Corporate Governance: The International Journal of Business in Society, Vol. 20 No. 5, pp. 821-836.

Mayer, R.C., Davis, J.H. and Schoorman, F.D. (1995), "An integrative model of organizational trust", The Academy of Management Review, Vol. 20 No. 3, pp. 709-734.

Migliore, L.A. and Horton DeClouette, A. (2011), "Perceptions of trust in the boardroom: a conceptual model", Journal of Leadership \& Organizational Studies, Vol. 18 No. 3, pp. 320-333.

Mnif, Y. and Borgi, H. (2020), "The association between corporate governance mechanisms and compliance with IFRS mandatory disclosure requirements: evidence from 12 African countries", Corporate Governance: The International Journal of Business in Society, Vol. 20 No. 7, pp. 1371-1392.

Morais, F., Kakabadse, A. and Kakabadse, N. (2018), "The chairperson and CEO roles interaction and responses to strategic tensions", Corporate Governance: The International Journal of Business in Society, Vol. 18 No. 1, pp. 143-164.

Morais, F., Kakabadse, A. and Kakabadse, N. (2020), "Leading through discontinuous change: a typology of problems and leadership approaches in UK boards", Long Range Planning, Vol. 53 No. 2, p. 101870. 
Mostovicz, E.I., Kakabadse, A. and Kakabadse, N.K. (2011), "The four pillars of corporate responsibility: ethics, leadership, personal responsibility and trust", Corporate Governance: The International Journal of Business in Society, Vol. 11 No. 4, pp. 489-500.

Muchemwa, M.R., Padia, N. and Callaghan, C.W. (2016), "Board composition, board size and financial performance of Johannesburg stock exchange companies", South African Journal of Economic and Management Sciences, Vol. 19 No. 4, pp. 497-513.

Muth, M.M. and Donaldson, L. (1998), "Stewardship theory and board structure: a contingency approach", Corporate Governance, Vol. 6 No. 1, pp. 5-28.

Nicholson, G.J., Pugliese, A. and Bezemer, P.J. (2017), "Habitual accountability routines in the boardroom: how boards balance control and collaboration", Accounting, Auditing \& Accountability Journal, Vol. 30 No. 2, pp. 222-246.

O’Boyle, I., Shilbury, D. and Ferkins, L. (2020), "Leadership in and out of the sport boardroom: new empirical insights", European Sport Management Quarterly, pp. 1-19, doi: 10.1080/ 16184742.2020.1838591.

Payne, G. and Williams, M. (2005), "Generalization in qualitative research", Sociology, Vol. 39 No. 2, pp. 295-314.

Piderit, S.K. (2000), "Rethinking resistance and recognizing ambivalence: a multidimensional view of attitudes toward an organizational change", The Academy of Management Review, Vol. 25 No. 4, pp. 783-794.

Price, M., Harvey, C., Maclean, M. and Campbell, D. (2018), "From Cadbury to Kay: discourse, intertextuality and the evolution of UK corporate governance", Accounting, Auditing \& Accountability Journal, Vol. 31 No. 5, pp. 1542-1562, doi: 10.1108/AAAJ-01-2015-1955.

Raza-Ullah, T. and Kostis, A. (2020), "Do trust and distrust in coopetition matter to performance?", European Management Journal, Vol. 38 No. 3, pp. 367-376.

Reeves, C.L. (2010), "A difficult negotiation: fieldwork relations with gatekeepers", Qualitative Research, Vol. 10 No. 3, pp. 315-331.

Roberts, J. (2001), "Trust and control in Anglo-American systems of corporate governance: the individualizing and socializing effects of processes of accountability", Human Relations, Vol. 54 No. 12, pp. 1547-1572.

Roberts, J., McNulty, T. and Stiles, P. (2005), "Beyond agency conceptions of the work of the nonexecutive director: creating accountability in the boardroom", British Journal of Management, Vol. 16 No. s1, pp. S5-S26.

Robinson, S.L. and Rousseau, D.M. (1994), "Violating the psychological contract: not the exception but the norm", Journal of Organizational Behavior, Vol. 15 No. 3, pp. 245-259.

Ross, C.E., Mirowsky, J. and Pribesh, S. (2001), "Powerlessness and the amplification of threat: neighborhood disadvantage, disorder and mistrust", American Sociological Review, Vol. 66 No. 4, pp. 568-591.

Rousseau, D.M. (2006), "Is there such a thing as 'evidence-based management'?", Academy of management review, Vol. 31 No. 2, pp. 256-269.

Rousseau, D.M., Sitkin, S.B., Burt, R.S. and Camerer, C. (1998), "Not so different after all: across discipline view of trust", Academy of Management Review, Vol. 23 No. 3, pp. 393-404.

San Martín-Rodríguez, L., Beaulieu, M.D., D’Amour, D. and Ferrada-Videla, M. (2005), "The determinants of successful collaboration: a review of theoretical and empirical studies", Journal of Interprofessional Care, Vol. 19 No. sup1, pp. 132-147.

Saunders, M.N.K. and Thornhill, A. (2004), "Trust and mistrust in organizations: an exploration using an organizational justice framework", European Journal of Work and Organizational Psychology, Vol. 13 No. 4, pp. 493-515.

Schillemans, T. and Bjurstrøm, K.H. (2020), "Trust and verification: balancing agency and stewardship theory in the governance of agencies", International Public Management Journal, Vol. 23 No. 5, pp. 650-676.

Schoorman, D.F., Mayer, R.C. and Davis, J.H. (2007), "An integrative model of organization trust: past, present and future”, Academy of Management Review, Vol. 32 No. 2, pp. 344-354. 
Shipley, R. and Kovacs, J.F. (2008), "Good governance principles for the cultural heritage sector: lessons from international experience", Corporate Governance: The International Journal of Business in Society, Vol. 8 No. 2, pp. 21-228.

Silvestri, A. and Veltri, S. (2017), "Ethical strategic alliances for the sustainable recovering of a territory", Corporate Governance: The International Journal of Business in Society, Vol. 17 No. 2, pp. 230-249.

Sitkin, S.D. and Roth, N.L. (1993), "Explaining the limited effectiveness of legalistic 'remedies' for trust/ distrust”, Organization Science, Vol. 4 No. 3, pp. 367-392.

Skinner, D. and Spira, L.F. (2003), "Trust and control-a symbiotic relationship?", Corporate Governance: The International Journal of Business in Society, Vol. 3 No. 4, pp. 28-35.

Skinner, D., Dietz, G. and Weibel, A. (2013), "The dark side of trust: when trust becomes a 'poisoned chalice'”, Organization Science, Vol. 21 No. 2, pp. 206-224.

Sørensen, O.H., Hasle, P. and Pejtersen, J.H. (2011), "Trust relations in management of change", Scandinavian Journal of Management, Vol. 27 No. 4, pp. 405-417.

Sundaramurthy, C. and Lewis, M. (2003), "Control and collaboration: paradoxes of governance", Academy of Management Review, Vol. 28 No. 3, pp. 397-415.

Sur, S. (2014), "Making sense of board effectiveness: a socio-cognitive perspective", Corporate Governance, Vol. 14 No. 2, pp. 162-180.

Taljaard, C.C., Ward, M.J. and Muller, C.J. (2015), "Board diversity and financial performance: a graphical time-series approach", South African Journal of Economic and Management Sciences, Vol. 18 No. 3, pp. 425-447.

Tihanyi, L., Graffin, S. and George, G. (2015), "From the editors: rethinking governance in management research", Academy of Management Journal, Vol. 1015 No. 1, pp. 1-9.

Tomlinson, E.C. and Mayer, R.C. (2009), "The role of causal attribution dimensions in trust repair", Academy of Management Review, Vol. 34 No. 1, pp. 85-104.

Tsamenyi, M., Enninful-Adu, E. and Onumah, J. (2007), "Disclosure and corporate governance in developing countries: evidence from Ghana", Managerial Auditing Journal, Vol. 22 No. 3, pp. 319-334.

Tshipa, J., Brummer, L.M., Wolmarans, H. and Du Toit, E. (2018), "The effect of industry nuances on the relationship between corporate governance and financial performance: evidence from South African listed companies", South African Journal of Economic and Management Sciences, Vol. 21 No. 1, pp. 1-18.

Tuggle, C.S., Schnatterly, K. and Johnson, R. (2010), "Attention patterns in the boardroom: how board composition and processes affect discussion of entrepreneurial issues", Academy of Management Journal, Vol. 53 No. 3, pp. 550-571.

Vollstedt, M. (2015), "'To see the wood for the trees: the development of theory from empirical interview using grounded "theory", in Bikner-Ahsbahs, A., Knipping, C. and Presmeg, N. (Eds), Approaches to Qualitative Research in Mathematics Education, Springer, Bremen, pp. 23-48.

Watson, C., Husband, G. and Ireland, A. (2021), "Opening the 'black box': what does observational research reveal about processes and practices of governing?", Journal of Management and Governance, Vol. 25 No. 1, pp. 189-221.

Weick, K.E. (1993), "The collapse of sensemaking in organizations: The Mann Gulch disaster", Administrative Science Quarterly, Vol. 38 No. 4, pp. 628-652.

Westphal, J.D. (1999), "Collaboration in the boardroom: behavioural and performance consequences of CEO-board ties", Academy of Management Journal, Vol. 42, pp. 7-24.

Westphal, J.D. and Zajac, E.J. (1995), "Who shall govern? CEO/board power, demographic similarity and new director selection", Administrative Science Quarterly, Vol. 40 No. 1, pp. 60-83.

Westphal, J.D. and Gulati, R. (1999), "Cooperative or controlling? The effects of CEO-board relations and the content of interlocks on the formation of joint ventures", Administrative Science Quarterly, Vol. 44 No. 3, pp. 473-506.

Withers, M.C. and Fitza, M.A. (2017), "Do board chairs matter? The influence of board chairs on firm performance", Strategic Management Journal, Vol. 38 No. 6, pp. 1343-1355.

Withers, M.C., Hillman, A.J. and Cannella, A.A. (2012), "A multidisciplinary review of the director selection literature", Journal of Management, Vol. 38 No. 1, pp. 243-277. 
Wright, P., Mukherji, A. and Kroll, M.J. (2001), "A re-examination of agency theory assumptions: extensions and extrapolations", The Journal of Socio-Economics, Vol. 30 No. 5, pp. 413-429.

Yenkey, C.B. (2018), "The outsider's advantage: distrust as a deterrent to exploitation", American Journal of Sociology, Vol. 124 No. 3, pp. 613-663.

Yin, R.K. (2009), '“Case study research: Design and methods", in Bickman, L. and Rog, D.J. (Eds), Essential Guide to Qualitative Methods in Organizational Research, Sage Publications, London and Singapore, Vol. 5.

\section{Further reading}

Ackroyd, S. (2010), "'Critical realism, organization theory, methodology and the emerging science of 'reconfiguration", in Koslowski, P. (Ed.), Elements of a Philosophy of Management and Organization, Studies in Economic Ethics and Philosophy, Springer-Verlag, Berlin Heidelberg, pp. 47-77.

Bhaskar, R. (1978), "On the possibility of social scientific knowledge and the limits of naturalism", Journal for the Theory of Social Behaviour, Vol. 8 No. 1, pp. 1-28.

Francoeur, C., Aubé, C., Sponem, S. and Farzaneh, F. (2018), "What do we know about what is going on inside the boardroom?", Team Performance Management: An International Journal, Vol. 24 Nos 5/6, pp. 250-264, doi: 10.1108/TPM-07-2017-0033.

Høgevold, N.M. and Svensson, G. (2016), "Framing the development and directions of business sustainability efforts", Corporate Governance, Vol. 16 No. 4, pp. 709-725.

Langfred, C.W. (2004), "Too much of a good thing? Negative effects of high trust and individual autonomy in self-managing teams", Academy of Management Journal, Vol. 47 No. 3, pp. 385-399.

Lewicki, R.J., Tomlinson, E.C. and Gillespie, N. (2006), "Models of interpersonal trust development: theoretical approaches, empirical evidence and future directions", Journal of Management, Vol. 32 No. 6 , pp. 991-1022.

Li, L., McMurray, A., Xue, J., Liu, Z. and Sy, M. (2018), "Industry-wide corporate fraud: the truth behind the Volkswagen scandal”, Journal of Cleaner Production, Vol. 172, pp. 3167-3175.

Sachs, S. and Ruehli, E. (2005), "Changing managers' values towards a broader stakeholder orientation", Corporate Governance: The International Journal of Business in Society, Vol. 5 No. 2, pp. 85-98.

Saunders, M.N.K., Dietz, G. and Thornhill, A. (2014), "Trust and distrust: polar opposites, or independent but co-existing?”, Human Relations, Vol. 67 No. 6, pp. 639-665.

Weick, K.E. (1989), "Theory construction as disciplined imagination", Academy of Management Review, Vol. 14 No. 4, pp. 516-531.

\section{Corresponding author}

Morris Mthombeni can be contacted at: mthombenim@gibs.co.za

For instructions on how to order reprints of this article, please visit our website: www.emeraldgrouppublishing.com/licensing/reprints.htm

Or contact us for further details: permissions@emeraldinsight.com 